\title{
Effect of whey protein and a free amino acid mixture simulating whey protein on measures of satiety in normal-weight women
}

\author{
Sylvia M. S. Chungchunlam ${ }^{1 *}$, Sharon J. Henare ${ }^{1}$, Siva Ganesh ${ }^{2}$ and Paul J. Moughan ${ }^{1}$ \\ ${ }^{1}$ Riddet Institute, Massey University, Private Bag 11-222, Palmerston North 4442, New Zealand \\ ${ }^{2}$ AgResearch Grasslands Research Centre, Tennent Drive, Private Bag 11-008, Palmerston North 4442, New Zealand \\ (Submitted 21 December 2015 - Final revision received 17 September 2016 - Accepted 3 October 2016)
}

\section{Abstract}

Dietary protein is considered more satiating than carbohydrate, and whey protein is more satiating than other protein sources. The purported satiating effect of whey protein may be due to direct effects of the unique mixture of proteins in whey, due to the effects of peptides released upon digestion and/or its amino acid composition. The objective of the present study was to compare the satiating effects of intact whey protein isolate (WPI) or a free amino acid mixture (AAM) simulating the amino acid composition of the WPI. A single-blind completely randomised block design included twenty, healthy, adult women (age $24 \cdot 2$ ( SEM 0.8) years) of normal weight (BMI $22 \cdot 7$ (SEM $0 \cdot 4) \mathrm{kg} / \mathrm{m}^{2}$ ). Following consumption of isoenergetic (approximately $1800 \mathrm{~kJ}$ ) preload meals enriched $(52 \mathrm{~g}$ amino acid equivalent) with WPI or AAM, consumption of an ad libitum test meal 120 min later and subjective feelings of appetite using visual analogue scales (VAS) were determined. There were no significant differences $(P=0.24)$ in the ad libitum test meal intakes between the WPI (268.5 (SEM 27.3) g) and the AAM (238.4 (SEM 22.7) g) preload meals. Subjective VAS ratings of appetite did not differ significantly between the WPI and the AAM preload meals $(P>0.05)$. Intact whey protein and a free AAM simulating the whey protein showed similar effects on satiety. This suggests that the satiating effect of whey protein may be related to its specific amino acid composition.

Key words: Satiety: Food intake: Whey protein: Amino acids: Human nutrition

There is considerable evidence that dietary proteins, in general, are more satiating than carbohydrate and fat ${ }^{(1-5)}$, and that among protein sources dairy whey protein is particularly satiating ${ }^{(6-8)}$. In comparison with carbohydrate, ingestion of whey protein has been shown to reduce subsequent energy intake relative to glucose $^{(9,10)}$, sucrose $\mathrm{s}^{(11)}$ or maltodextrin ${ }^{(12-14)}$. In our own earlier study with healthy, normal-weight human subjects ${ }^{(13-15)}$, we found that whey protein, when provided as the main fraction of a preload meal, suppressed subsequent food intake and increased subjective ratings of fullness relative to maltodextrin. Consumption of whey protein has been shown to result in a greater reduction in subsequent food intake and increase in subjective ratings of satiety compared with casein ${ }^{(16,17)}$, egg albumen ${ }^{(11,18)}$, milk protein ${ }^{(19)}$, soya protein ${ }^{(17)}$, tuna ${ }^{(18)}$ and turkey meat ${ }^{(18)}$. However, little is known about the characteristics of whey that elicit such an effect on satiety. The satiating effect of whey protein may be attributed to an effect of the intact proteins themselves, to the bioactive peptides released during digestion ${ }^{(20,21)}$ or to the unique amino acid composition of whey protein.

Proteins release peptides and amino acids into the digestive lumen during digestion, and amino acids are transferred to the blood via amino acid transport systems present in the intestinal mucosa ${ }^{(22,23)}$. A previous study by Mellinkoff et $a l .{ }^{(24)}$ showed that an increase in postprandial peripheral serum amino acid concentrations was associated with a reduction in subjective ratings of hunger. The satiating effect of whey protein may be related to its rapid digestion and amino acid absorption ${ }^{(16,23,25)}$, resulting in rapid increases in plasma amino acid concentrations ${ }^{(16,17,26-28)}$. Moreover, whey protein is a rich source of branched-chain amino acids (BCAA) such as isoleucine, leucine and valine ${ }^{(29,30)}$, and this is reflected in the postprandial plasma BCAA concentrations observed after whey protein intake ${ }^{(16,17,26-28,31)}$. The satiating effect of intact whey protein has not been compared with that of a free amino acid mixture (AAM) simulating its amino acid content.

The objective of the present study was to assess whether the satiating effect of whey protein is related to its mixture of intact proteins or to the unique amino acid composition of whey protein. The effects of a whey protein isolate (WPI) compared with its equivalent AAM given in the free form on subsequent ad libitum food intake and subjective ratings of appetite were studied in healthy, normal-weight, young women. Testing a hypothesis concerning the effects of amino acids requires an

Abbreviations: AAM, amino acid mixture; BCAA, branched-chain amino acids; ME, metabolisable energy; net iAUC, net incremental AUC; VAS, visual analogue scale; WPI, whey protein isolate.

* Corresponding author: S. M. S. Chungchunlam, email sylvia.lawrence.17@gmail.com 
accurate assessment of the amino acid composition of the protein, and therefore multiple hydrolysis times combined with least-squares non-linear regression was used to obtain the amino acid composition of WPI in this study.

\section{Methods \\ Subjects}

A total of twenty women, aged 18-40 years, with a BMI ranging from 19 to $26 \mathrm{~kg} / \mathrm{m}^{2}$, responded to a public advertisement and were invited to participate in the present study. Subjects were screened for exclusion criteria that included smoking, athletic training, a gastrointestinal disorder or eating disorder, dieting or taking medication known to affect appetite, not consuming breakfast every day, having a history of menstrual irregularities, pregnancy, lactation or trying to become pregnant. All subjects had their height and weight measured in the laboratory to ensure that they met the BMI criteria. Before the start of the study, participants tasted all test meals, and subjects who had intolerance to the test foods or disliked the test foods were not included in the study. Subjects completed the Three Factor Eating Questionnaire ${ }^{(32)}$ as a measure of dietary restraint (mean score 9 (SEM 1), range 1-21). All volunteers provided their written informed consent. The present study was conducted according to the guidelines laid down in the Declaration of Helsinki, and all procedures involving human subjects were approved by the Massey University Human Ethics Committee (application no. 11/47). The human trial was registered with the Australian New Zealand Clinical Trials Registry (www. anzctr.org.au) as ACTRN12615000344594.

\section{Amino acid analysis of the whey protein isolate}

It was necessary to determine with accuracy the amino acid composition of the WPI. The WPI was hydrolysed in concentrated 6-M-hydrochloric acid $(\mathrm{HCl})$ containing $0 \cdot 1 \%(\mathrm{v} / \mathrm{v})$ phenol. The hydrolysates were sealed in an $\mathrm{O}_{2}$-free environment and then hydrolysed at $110^{\circ} \mathrm{C}$ for $0,2,4,6,10,14,19,24,52,92$ and $144 \mathrm{~h}$ to determine amino acids (excluding tryptophan, cysteine, methionine, asparagine and glutamine). The hydrolysates were dried under vacuum and dissolved in sodium citrate buffer $(\mathrm{pH}$ 2.2). Cysteine and methionine were oxidised with performic acid to cysteic acid and methionine sulfone, respectively, before $\mathrm{HCl}$ hydrolysis. Tryptophan was determined following alkaline (sodium hydroxide) hydrolysis of the protein in a $\mathrm{N}_{2}$ environment at $110^{\circ} \mathrm{C}$ for $0,2,4,6,10,14,20,24,52,92$ and $144 \mathrm{~h}$. After hydrolysis of the sample protein, the amino acids were separated and quantified using HPLC. The WPI powder used in the present study was analysed for amino acid composition $^{(33)}$ (Table 1) at the Riddet Institute (Palmerston North, New Zealand) using multiple hydrolysis times (0-144h) combined with least-squares non-linear regression ${ }^{(34,35)}$ as described in detail in the protocol of Rutherfurd \& Gilani ${ }^{(36)}$

\section{Test foods}

The breakfast meal consisted of toasted wholemeal bread and a selection of margarine, strawberry jam and either coffee or tea plus white sugar and full-fat milk. The same subject-specific breakfast was provided in packed containers before each study day, and participants were instructed to consume all the food items provided. Breakfast consumption of each participant was recorded on each study day. The average metabolisable energy (ME) content of the breakfast meal was $1503 \mathrm{~kJ}$ with 57, 11 and $32 \%$ of ME being derived from carbohydrate, protein and fat, respectively.

The preloads consisted of toast and an orange-flavoured spread. The two test preload spreads consisted of an orangeflavoured marmalade (Jok'N'Al Orange marmalade; Joknal Products Ltd, $255 \mathrm{~kJ}$ ME, $0.3 \mathrm{~g}$ protein, $15.0 \mathrm{~g}$ carbohydrate and $0 \mathrm{~g}$ fat/100 g serve) to which either a WPI or a mixture of free amino acids simulating the amino acid composition of whey protein (AAM) was added. A 50-g serve of protein was provided in the preload on the basis of the amount of protein observed to induce satiety in our previous studies ${ }^{(13,14)}$. The WPI preload spread contained $60 \mathrm{~g}$ of dairy WPI (WPI 894; Fonterra Co-operative Group Ltd) mixed with $190 \mathrm{~g}$ of orange-flavoured marmalade, and was prepared in the laboratory 1 week before the study start and stored in a refrigerator. The AAM preload spread contained $50 \mathrm{~g}$ of the mixture of free amino acids and $200 \mathrm{~g}$ of orangeflavoured marmalade, and was freshly prepared on each test day. The AAM composition was equivalent to that of the WPI (Table 1) and was obtained by mixing pure, crystalline, free amino acids (Evonik Degussa $\mathrm{GmbH}$ ). All amino acids were single L-amino acids of food grade, except for glycine and methionine (DL-methionine). The amino acid content of L-cysteine was adjusted for the presence of $\mathrm{HCl}$ and water, and the amino acid content of L-lysine was adjusted for the presence of $\mathrm{HCl}$. The amounts of L-asparagine and L-aspartic acid $(5.10$ and $7.08 \mathrm{~g}$, respectively, per $100 \mathrm{~g}$ WPI powder) as well as the amounts of L-glutamine and L-glutamic acid (6.40 and $11.25 \mathrm{~g}$, respectively, per $100 \mathrm{~g}$ WPI powder) added to the AAM were estimated on the basis of the ratio contained in the WPI. To improve palatability, each preload spread ( $250 \mathrm{~g}$ ) was accompanied with a slice ( $45 \mathrm{~g})$ of toasted low-protein bread (Pavilion original sliced gluten-free bread; Pavillion Foods, $444 \mathrm{~kJ}$ ME, $1.2 \mathrm{~g}$ protein, $22.7 \mathrm{~g}$ carbohydrate and $1.2 \mathrm{~g}$ fat $/ 45 \mathrm{~g}$ serve) and $100 \mathrm{ml}$ of water. The bread was common to both preload diets and contributed a low amount of protein ( $1.2 \mathrm{~g}$ protein per preload meal). The amino acid composition of the bread was not determined. The WPI-enriched preload meal $(295 \mathrm{~g}, 1849 \mathrm{~kJ} \mathrm{ME}$ ) contributed $52.8 \mathrm{~g}$ protein, $53.9 \mathrm{~g}$ carbohydrate and $1.8 \mathrm{~g}$ fat, and the AAM-enriched preload meal $(295 \mathrm{~g}, 1790 \mathrm{~kJ} \mathrm{ME})$ contributed $51.8 \mathrm{~g}$ protein, $52.7 \mathrm{~g}$ carbohydrate and $1.2 \mathrm{~g}$ fat. The two test preloads were approximately isoenergetic (approximately $1800 \mathrm{~kJ}$ ) and similar in the proportional energy provided by protein (48.6-49.2\% of ME), carbohydrate (47.7-48.3\% of ME) and fat (2.5-3.7\% of ME).

A lunchtime test meal was served in private cubicles $120 \mathrm{~min}$ following consumption of the preload meals and comprised of a homogeneous, single-item, hot fried-rice meal and bottled spring water. The hot fried-rice test meal included white rice, minced chicken meat, eggs, peas, maize, carrots, chicken stock, salt, sugar and vegetable oil. The fried-rice test meal contained $36 \cdot 8,8 \cdot 5,5 \cdot 8$ and $1.0 \mathrm{~g}$ of available carbohydrate, crude protein, crude fat and total dietary fibre, respectively, per $100 \mathrm{~g}$, with a calculated ME content of $982 \mathrm{~kJ} / 100 \mathrm{~g}$. 


\section{Experimental procedure}

In a single-blind, completely randomised block design, each woman subject served as her own control by participating in 2 session days, with a minimum of $2 \mathrm{~d}$ between test days. On the evening preceding each test day, subjects were instructed to abstain from strenuous physical activity and alcohol consumption, and to consume only water after 22.00 hours. Women participated during the early phase of their menstrual cycle (menstruation and follicular phase). On the morning of the test day, each subject consumed a subject-specific breakfast meal at home. The participants were instructed to consume all the food items provided at least $3 \mathrm{~h}$ before the test session appointment. Throughout the morning, participants were instructed to refrain from consuming anything except water.

Subjects arrived at the Human Nutrition Unit, Massey University, approximately 12.00 to 13.00 hours. Subjects who did not comply with restrictions on the evening before and the morning were re-scheduled for another test day. Upon arrival at the laboratory, a baseline questionnaire to assess ratings of appetite (hunger, desire to eat, prospective food consumption and fullness) and nausea was completed. A test preload meal was served to be consumed within $15 \mathrm{~min}$. Following complete ingestion of the preload meal (time $0 \mathrm{~min}$ ), subjects completed a questionnaire assessing the palatability of the preload meal. Ratings of appetite and nausea were measured at 0, 15, 30, 45, 60, 75, 90 and $120 \mathrm{~min}$. Following the 120-min measurement, subjects were seated in individual cubicles to consume the lunchtime test meal within $15 \mathrm{~min}$. Subjects were instructed to consume the test meal at will (ad libitum) until such point where they felt comfortably full. Subjects rated the likeability of the fried-rice test meal immediately after consumption using a questionnaire. Subjects also completed questionnaires to assess subjective ratings of appetite and nausea 15 and $30 \mathrm{~min}$ after consumption of the lunchtime test meal. This experimental protocol has been described in detail previously $^{(13,14,33)}$.

\section{Measures of satiety}

The amounts of the fried-rice test meal and water, which were provided without restriction at lunch, were measured before and after consumption using an electronic scale to the nearest $0 \cdot 01 \mathrm{~g}$. Subjects rated the palatability of the preload drink (overall likeability, pleasantness of taste, likeability of texture and overall sweetness) and overall likeability of the fried-rice test meal using a $10-\mathrm{cm}$ visual analogue scale (VAS) immediately after consumption. The VAS was end-anchored with 'dislike extremely' and 'like extremely' for ratings of overall likeability and likeability of texture and with 'not at all' and 'extremely' for ratings of pleasantness of taste and sweetness. Each subject was instructed to fill in a booklet of questionnaires to assess subjective ratings of appetite (hunger, desire to eat, prospective food consumption and fullness) and nausea. Ratings were made on a $10-\mathrm{cm}$ VAS labelled at each end with extremes: 'not at all' and 'extremely' for hunger, fullness and nausea; 'very weak' and 'very strong' for desire to eat; and 'nothing at all' and 'a large amount' for prospective consumption. VAS-rated appetite and nausea scores were collected immediately before consuming the test preload (baseline), during a 120-min period following consumption of the test preload $(0,15,30,45,60,75,90$ and $120 \mathrm{~min})$ and 15 and $30 \mathrm{~min}$ following consumption of the lunchtime ad libitum test meal.

\section{Statistical analysis}

Statistical analyses were performed using Statistical Analysis Systems statistical software package version 9.2 for WINDOWS (SAS Institute). Power analysis, based on results from previous studies $^{(13,14)}$, indicated that a sample size of thirteen female subjects had sufficient power of $80 \%$ at a level of significance of 0.05 to allow the detection of differences in ad libitum test meal intake. Each variable was examined for normal distribution and the presence of statistical outliers ${ }^{(37)}$. Comparisons between the two preload meals were evaluated using two-tailed paired $t$ tests, pairing on subject, for VAS-rated palatability scores of preload meal and test meal $(\mathrm{cm})$, water $(\mathrm{g})$, test meal ( $\mathrm{g}$ and $\mathrm{kJ} \mathrm{ME}$ ) and total energy (preload+test meal, kJ ME) intakes. A $P$ value $<0.05$ was considered statistically significant. Duncan's multiple-range test was used for making multiple pair-wise treatment comparisons. A repeated-measures ANOVA was used to evaluate the effect of preload, time of rating and their interaction (preload $\times$ time) on VAS-rated feelings of hunger, desire to eat, prospective food consumption, fullness and nausea. In the case of a significant interaction between preload and time $(P<0.05)$, paired multiple comparisons were used to examine the preload and time combinations. VAS-rated feelings of appetite and nausea were also reported as net incremental AUC (net iAUC) from 0 to $120 \mathrm{~min}$ using the trapezoidal rule and evaluated using two-tailed paired $t$ tests, pairing on subject. Results are expressed as means with their standard errors. Pearson's correlation analysis was performed to test the relationship between energy intake (kJ ME) at the lunchtime ad libitum test meal and palatability of the preload as well as VAS-rated feelings of appetite and nausea.

\section{Results}

\section{Amino acid analysis of the whey protein isolate}

The estimated protein-bound amino acid content determined using the least-squares non-linear regression model $\left(A_{0}\right)$ and the mean amino acid content after $24 \mathrm{~h}$ ( $20 \mathrm{~h}$ for tryptophan) of hydrolysis for each amino acid are presented in Table 1 . The greatest difference was observed for tryptophan, which was underestimated by $23.1 \%$ after $20 \mathrm{~h}$ of alkaline hydrolysis. Glycine, proline, serine and threonine were also underestimated by $6.9,4 \cdot 8,10 \cdot 3$ and $4.9 \%$, respectively. The standard 24-h hydrolysis method overestimated the amino acid content of aspartic acid (3.5\%), glutamic acid (1.6\%), histidine (2.1\%) and methionine (determined as methionine sulfone) (2.5\%). These results highlight that when accurate amino acid compositional data are needed, the previously validated ${ }^{(34,35)}$ multiple hydrolysis method should be used. 
Table 1. Amino acid composition ( $\mathrm{g} / 100 \mathrm{~g}$ powder, $A_{0}$ ) of the whey protein isolate determined using a least-squares non-linear regression model after multiple hydrolysis times compared with standard 24-h hydrolysis values (Mean values with their standard errors)

\begin{tabular}{|c|c|c|c|c|c|}
\hline \multirow{2}{*}{$\begin{array}{l}\text { Amino acid } \\
(\mathrm{g} / 100 \mathrm{~g} \text { powder })^{\star}\end{array}$} & \multicolumn{2}{|c|}{$A_{0}$} & \multicolumn{2}{|c|}{ 24-h } & \multirow{2}{*}{$\begin{array}{l}\text { Difference } \\
(\%) \dagger\end{array}$} \\
\hline & Mean & SEM & Mean & SEM & \\
\hline Ala & $5 \cdot 21$ & 0.10 & $5 \cdot 17$ & 0.05 & 0.9 \\
\hline Arg & $2 \cdot 32$ & 0.05 & $2 \cdot 31$ & 0.04 & 0.5 \\
\hline Asp & $12 \cdot 18$ & 0.31 & $12 \cdot 62$ & 0.48 & -3.5 \\
\hline Cysł & $2 \cdot 15$ & 0.04 & $2 \cdot 14$ & 0.01 & 0.6 \\
\hline Glu & 17.66 & 0.39 & 17.94 & 0.17 & $-1 \cdot 6$ \\
\hline Gly & 1.43 & 0.04 & 1.33 & 0.01 & 6.9 \\
\hline His & 1.43 & 0.03 & 1.46 & 0.01 & $-2 \cdot 1$ \\
\hline Ile & 6.41 & 0.14 & 6.40 & 0.06 & 0.1 \\
\hline Leu & 9.94 & 0.20 & 9.89 & 0.08 & 0.5 \\
\hline Lys & 8.07 & 0.17 & 8.01 & 0.20 & 0.7 \\
\hline Met§ & 2.55 & 0.04 & 2.62 & 0.02 & -2.6 \\
\hline Phe & $2 \cdot 74$ & 0.06 & 2.72 & 0.01 & 0.8 \\
\hline Pro & 5.45 & 0.11 & $5 \cdot 19$ & 0.32 & 4.8 \\
\hline Ser & 4.51 & 0.10 & 4.05 & 0.09 & $10 \cdot 3$ \\
\hline Thr & 7.02 & 0.12 & 6.68 & 0.06 & 4.9 \\
\hline Trp & 1.60 & 0.04 & $1.23 \|$ & $0.39 \|$ & 23.19 \\
\hline Tyr & $2 \cdot 78$ & 0.06 & 2.77 & 0.01 & 0.3 \\
\hline Val & 5.65 & 0.13 & 5.68 & 0.03 & -0.5 \\
\hline
\end{tabular}

* Samples were analysed in triplicate.

$\dagger$ Difference $(\%)=\left(\left(A_{0}\right.\right.$ value-24-h value $) / A_{0}$ value $) \times 100$.

$\ddagger$ Detected as cysteic acid after performic acid oxidation followed by acid hydrolysis.

$\S$ Detected as methionine sulfone after performic acid oxidation followed by acid hydrolysis.

II 20-h hydrolysis value for tryptophan

I Difference $(\%)=\left(\left(A_{0}\right.\right.$ value $-20-\mathrm{h}$ value $) / A_{0}$ value $) \times 100$

\section{Subjects and nausea}

All twenty women were similar in age (24.2 (sem 0.8) years) and BMI $\left(22 \cdot 7(\right.$ SEM 0.4$\left.) \mathrm{kg} / \mathrm{m}^{2}\right)$. Subjects did not report any adverse effects upon consuming the preload meals. Following ingestion of the preload meals (from 0 to $120 \mathrm{~min}$ ), VAS-rated feelings of nausea $(P>0.05$, data not shown) and net iAUC for nausea (29.7 (sem 59.5) v. $-2.3(\operatorname{sem} 34.6) \mathrm{cm}, 120 \mathrm{~min}$, for the WPI and AAM preloads, respectively, $F_{1,19}=0.52, P=0.41$ ) did not differ significantly between the two preload conditions. Pearson's correlation indicated that there was no relationship between postprandial ratings of nausea (0-120 min) or net iAUC for nausea and energy intake at the lunchtime ad libitum test meal $(P>0 \cdot 05$, data not shown).

\section{Palatability of preload meals and test meal}

There were significant differences found in VAS ratings for overall likeability $\left(F_{1,19}=11.72, P=0.0029\right)$, pleasantness of taste $\left(F_{1,19}=12 \cdot 11, \quad P=0 \cdot 0025\right)$ and overall sweetness $\left(F_{1,19}=8 \cdot 14, P=0 \cdot 0102\right)$ between the two preloads. The AAM preload meal was rated as being the least liked (1.5 $(\operatorname{sem} 0.4) \mathrm{cm})$, least pleasant in taste $(1.4($ Sem 0.3$) \mathrm{cm})$ and least sweet $(3.3(\operatorname{SEM~} 0.6) \mathrm{cm})$ compared with the WPI preload meal $(3.9$ (SEM 0.7$) \mathrm{cm}, 4.3($ SEM 0.7$) \mathrm{cm}$ and 5.3 (SEM 0.6) $\mathrm{cm}$, respectively). There was no effect of preload on the ratings for likeability of texture $(4.4$ (SEM 0.6$) \mathrm{cm}$ and 3.3 (SEM 0.5$) \mathrm{cm}$ for the WPI and AAM preload meals, respectively, $F_{1,19}=2 \cdot 77$,
$P=0 \cdot 11)$. Pearson's correlation analysis showed that the VAS scores for overall likeability $(r-0 \cdot 17, P=0 \cdot 28)$, pleasantness of taste $(r-0 \cdot 14, P=0 \cdot 35)$, likeability of texture $(r-0 \cdot 01, P=0.91)$ and overall sweetness $(r-0.01, P=0.95)$ of the preload meals were not correlated to energy intake at the subsequent test meal. The palatability of the lunchtime ad libitum test meal did not differ between the WPI and the AAM preload meals $\left(F_{1,19}=0 \cdot 13, P=0 \cdot 71\right)$, with a mean overall likeability score of $8.6($ SEM 0.2$) \mathrm{cm}$.

\section{Ad libitum test meal intake and total energy intake}

There were no significant differences in ad libitum water intake $\left(F_{1,19}=1.00, P=0.33\right)$, with the amount of water ingested at lunch being 393.2 (SEM 35.7) and 363.5 (SEM 45.6) $\mathrm{g}$ for the WPI and the AA preload meals, respectively. There was no significant effect of preload $\left(F_{1,19}=1.47, P=0.24\right)$ on the amount $(\mathrm{g})$ and energy intake (kJ ME) of the ad libitum friedrice test meal consumed at lunch. The amount and energy intake of the test meal ingested following consumption of the WPI preload were 268.5 (SEM 27.3) g and 2636.6 (SEM 268.5) kJ, respectively, and for the AAM preload 238.4 (SЕм 27.3) $\mathrm{g}$ and $2340 \cdot 6$ (SEM 223.1) kJ, respectively. When the energy intake from the preload meal was added to the ad libitum food test meal energy intake at lunch, total energy intake did not differ significantly between the two preload meals (4385.0 (SEM 271.1) and 4069.7 ( respectively, $\left.F_{1,19}=2 \cdot 11, P=0 \cdot 16\right)$.

\section{Subjective ratings of appetite}

When the total testing period (approximately $3 \mathrm{~h}$ ) was examined, there was no significant interaction between preload and time for the VAS-rated feelings of hunger $\left(F_{10,370}=0.47\right.$, $P=0.91)$, desire to eat $\left(F_{10,370}=0.14, P=0.99\right)$, prospective food consumption $\left(F_{10,370}=0.25, \quad P=0.99\right)$ or fullness ( $F_{10,360}=0.26, P=0.98$ ) (Fig. 1$)$. There was no significant main effect of preload $(P>0.05)$, but, as expected, there was a significant main effect of time $(P<0.0001)$ observed for each rating of appetite. When the ratings determined following consumption of the preload meal (0-120 min) were adjusted for baseline ratings, there was no significant interaction between preload and time observed for the VAS-rated feelings of hunger $\left(F_{7259}=0.59, P=0.76\right)$, desire to eat $\left(F_{7259}=0.32, P=0.94\right)$, prospective food consumption $\left(F_{7259}=0.37, P=0.91\right)$ or fullness $\left(F_{7252}=0 \cdot 47, P=0 \cdot 85\right)$. The appetite ratings did not differ significantly between preloads $(P>0 \cdot 05)$, but were influenced by time $(P<0.0001)$. The VAS-rated feelings of hunger, desire to eat, prospective food consumption and fullness expressed as net iAUC following consumption of the two preload meals (0-120 min) are shown in Fig. 1. There were no significant differences found in the net iAUC responses for the ratings of hunger $\left(F_{1,19}=2 \cdot 75, \quad P=0 \cdot 11\right)$, desire to eat $\left(F_{1,19}=0 \cdot 07\right.$, $P=0.79)$, prospective food consumption $\left(F_{1,19}=0.62, P=0.44\right)$ or fullness $\left(F_{1,19}=0.01, P=0.91\right)$ between the two preload conditions. Pearson's correlation analysis was performed to examine the relationship between energy intake at the subsequent test meal and subjective ratings of appetite immediately 

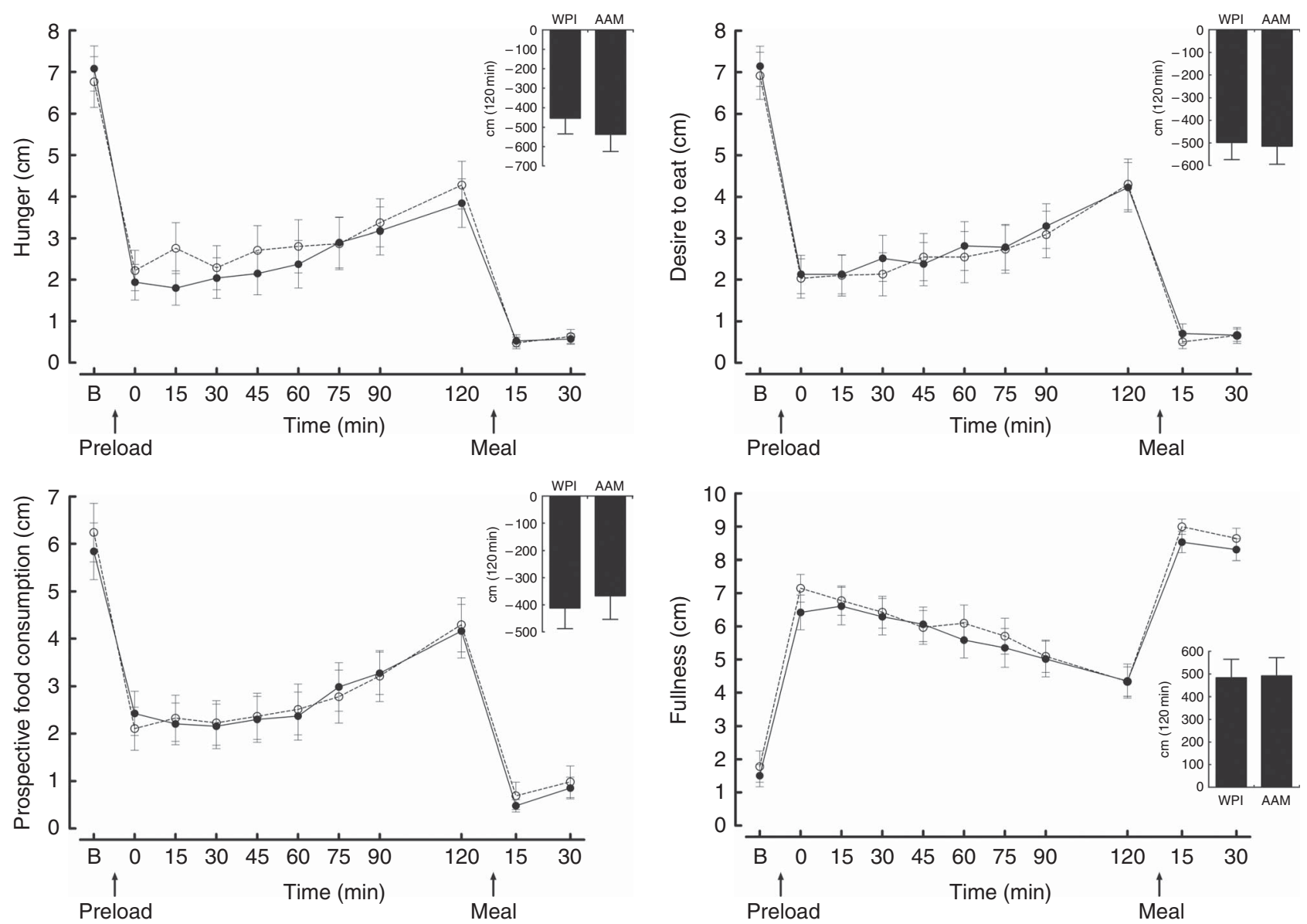

Fig. 1. Subjective visual analogue scales (VAS) ratings of hunger, desire to eat, prospective food consumption and fullness before (baseline, B) and after consumption of a preload meal enriched with either a whey protein isolate (WPI, -๑) or a free amino acid mixture (AAM, $\bullet$ ) simulating the amino acid composition of WPI (AAM), and 15 and $30 \mathrm{~min}$ following consumption of the ad libitum test meal. Values are means $(n 20)$ women, with their standard errors. There was no significant interaction between preload and time $(P>0.05)$, and there was no significant main effect of preload $(P>0.05)$, but each VAS-rated feeling differed by time $(P<0.0001)$. Inset: net incremental AUC from 0 to $120 \mathrm{~min}$ in response to ingestion of the two preload meals. There was no significant main effect of preload for each subjective rating $(P>0.05)$.

before consumption of the ad libitum test meal (120 min). Energy intake of the test meal was positively related to ratings of hunger $(r 0.33, P=0.0324)$ and prospective food consumption ( $r 0 \cdot 38, P=0 \cdot 0144)$, but was not correlated to ratings of desire to eat $(r 0 \cdot 22, P=0 \cdot 15)$ and fullness $(r-0 \cdot 10, P=0.53)$.

\section{Discussion}

Little is known about the aspects of whey protein that mediate its established ${ }^{(9-19,38)}$ relative satiating effect, but many studies have implicated a role of the pattern of amino acids absorbed $^{(39-43)}$ and the action of specific amino acids ${ }^{(44-51)}$. The aim of the present study was to evaluate whether the unique amino acid composition of whey protein plays a role in satiety, by comparing the effects of a preload meal containing intact WPI or a mixture of free amino acids simulating the amino acid composition of the WPI (AAM) on subsequent ad libitum food intake and subjective ratings of appetite in twenty women, where the amino acid composition of whey protein was known with a high degree of accuracy.

This study required the delivery of free amino acids simulating the amino acid composition of whey protein. This meant that the amino acid composition of whey protein needed to be determined with accuracy. The chemistry and stability of amino acids during acid hydrolysis used in amino acid analysis differ among amino acids, and the 24-h analysis time (20-h for tryptophan) represents a compromise relative to the optimal hydrolysis time across amino acids, leading to the maximal release of most amino acids from the protein while minimising amino acid degradation. The hydrolysis and degradation of amino acids occur simultaneously during hydrolysis, and this needs to be recognised when determining the amino acid composition of proteins. By determining the amino acid content using multiple hydrolysis times, and using a previously validated ${ }^{(34,35)}$ leastsquares non-linear regression to model the relationship between amino acid yield and hydrolysis time, the actual protein-bound amino acid content of a protein source can be estimated accurately. This method was used in the present study.

Dietary products based on free amino acids are generally low in palatability and may induce adverse responses because of their bitter taste ${ }^{(52,53)}$. The use of an orange-flavoured marmalade spread to mask the taste of free, crystalline amino acids was effective, with subjects reporting no adverse effects or differences in ratings of nausea following consumption of the 
amino acid-based diet. Although the preload meal containing the free amino acids was perceived as being the least liked (overall likeability), least pleasant in taste and least sweet in relation to the WPI preload meal, no correlation between the perceived sensory characteristics of the preload meal and subsequent food energy intake was observed, thus indicating that these dietary characteristics did not influence the outcomes of the study.

Ingestion of a preload meal containing similar amounts of carbohydrate and energy but enriched with WPI or AAM resulted in similar ad libitum intakes of water $(\mathrm{g})$ and food ( $\mathrm{g}$ and $\mathrm{kJ} \mathrm{ME}$ ) at a test meal $120 \mathrm{~min}$ after ingestion of the preload. Total energy intake (preload+test meal energy intakes) also did not differ between the preload meals. With respect to subjective ratings of hunger, desire to eat, prospective food consumption and fullness (VAS scores and net iAUC), there were no significant differences between the two preload meals. The VAS scores for the subjective ratings of appetite were found to be related, as would be expected, with subsequent food energy intake. The effect of intact whey protein on subsequent food intake and subjective ratings of appetite was reproduced when whey protein was replaced in the preload by free amino acids. The form of delivery of the amino acids did not influence the measures of satiety. These results suggest that the previously observed satiating effect of whey protein is related to its unique amino acid composition. Several studies have implicated a role of absorbed amino acids on voluntary food intake. A deficit of specific amino acids in the diet has been shown to result in a decrease in food intake ${ }^{(39-43)}$. Amino acids may play a role in the reduction of food intake and stimulation of satiety ${ }^{(24,54)}$.

This is the first study to compare the effects of intact whey protein and a mixture of free amino acids simulating the amino acid composition of whey protein on satiety in humans. One of the limitations of the present study is that we were unable to measure the rate of gastric emptying in subjects themselves and the concentrations of amino acids in the peripheral plasma, which may have helped in elucidating the postprandial kinetics of the two preload meals and would have extended the interpretation of the results. Nevertheless, in an accompanying study with the growing rat, stomach-emptying rates, determined using magnetic resonance spectroscopy, for the two experimental diets used here were found to be similar (see online Supplementary Material), suggesting similar rates of appearance of amino acids in the peripheral blood. The similar effect of preload meals enriched with whey protein or its equivalent free amino acids in inducing satiety, as observed in the present study, provides novel information that total amino acids (TAA), rather than constituent proteins and derived peptides, may be involved in the satiating response to whey protein. Several studies have reported more rapid increases in plasma TAA and BCAA following consumption of whey protein in comparison with other protein sources ${ }^{(16,17,19,25,27,28)}$. In our earlier study ${ }^{(26)}$, whey protein elicited a greater increase in plasma BCAA relative to maltodextrin, and a significant correlation $(P<0.05)$ between plasma concentrations of BCAA and satietyrelated hormones, glucagon-like peptide- 1 and pancreatic polypeptide, was observed. With regard to free amino acid meals, Nilsson et al. ${ }^{(28)}$ found that the increase in circulating levels of insulin following consumption of a drink containing whey protein appeared to be mimicked by ingestion of a drink containing equivalent amounts of free isoleucine, leucine, valine, lysine and threonine. These amino acids, naturally abundant in whey protein, may play a role in the reduction of food intake and stimulation of satiety ${ }^{(54)}$. Several studies have demonstrated a similar profile of circulating amino acids when proteins and an equivalent mixture of free amino acids were consumed $^{(55-58)}$. However, the literature on the effects of free amino acids on food intake and satiety in human subjects is limited. Ingestion of a capsule containing methionine, phenylalanine, tryptophan and valine reduced food intake 30 min later compared with a placebo capsule containing magnesium trisilicate ${ }^{(44)}$. Some amino acids thought to be involved in the regulation of food intake and body weight include leucine ${ }^{(45-47)}$, phenylalanine ${ }^{(48,49)}$ and tryptophan ${ }^{(50,51)}$. Although satiety and metabolic responses to the consumption of particular free amino acids have been studied, the contribution of the overall pattern of amino acids is less well known and needs further study.

In conclusion, consumption of both the whey proteincontaining diet and the free amino acid-containing diet influenced measures of satiety to a similar extent in normal-weight adult women. Thus, the parent protein and a free AAM simulating the amino acid composition of the parent protein induce the same degree of satiety. Importantly, this suggests that the mechanism involved in the effect of whey protein on satiety is mediated via the constituent amino acids, rather than the whole protein or bioactive peptides released during digestion or some combination of these. Although this study provides information concerning the effectors, it does not address possible mechanisms of the effect, and therefore the latter postulate awaits confirmation at the mechanistic level. These observations warrant further investigation by assessing the rate of whey protein digestion, the dynamics of uptake of dietary amino acids, the appearance of circulating amino acids and their potential mechanistic association with satiety responses. Concomitantly, there is a need for further studies to compare the satiating effects of whey protein with other protein sources. It is known that proteins differ in their amino acid composition, but it is not clear whether such differences are the underlying causes for reported differences between proteins in the promotion of satiety.

\section{Acknowledgements}

The authors thank the participants of the present study. The authors also thank Dr Derek Haisman and Vikas Mittal for their assistance in developing the preload meals, Maria-Tine Biersteker, Natascha Strobinger, Mehak Dhillon and Sumon Saha for their technical assistance, Dr Shane Rutherfurd for his advice on amino acid determination and the stomach-emptying rat trial, and Dr Carlos Montoya, Dr Jason Hindmarsh and Trent Olson for their assistance with the stomach-emptying rat trial.

The present study was funded by the Riddet Institute, a New Zealand government-supported Centre of Research Excellence. The authors are thankful to Fonterra Co-operative Group Ltd 
(New Zealand) for providing free samples of the whey protein isolate and Evonik Industries AG (Germany) for their generous donation of individual, pure, free amino acids.

The authors' contributions are as follows: S. M. S. C. oversaw the design and conduct of the study, analysed and interpreted the data, and led the drafting of the manuscript; S. J. H. assisted with the conduct of the study and contributed to the writing of the manuscript; S. G. contributed to data analysis and helped with manuscript writing; P. J. M. contributed to the study design and manuscript writing. S. M. S. C. and P. J. M. had primary responsibility for the final content.

The authors declare that there are no conflicts of interest.

\section{Supplementary material}

For supplementary material/s referred to in this article, please visit https://doi.org/10.1017/S0007114516003767

\section{References}

1. Anderson GH \& Moore SE (2004) Dietary proteins in the regulation of food intake and body weight in humans. J Nutr 134, S974-S979.

2. Eisenstein J, Roberts SB, Dallal G, et al. (2002) High-protein weight-loss diets: are they safe and do they work? A review of the experimental and epidemiologic data. Nutr Rev $\mathbf{6 0}$, 189-200.

3. Halton TL \& Hu FB (2004) The effects of high protein diets on thermogenesis, satiety and weight loss: a critical review. J Am Coll Nutr 23, 373-385.

4. Westerterp-Plantenga MS, Nieuwenhuizen A, Tome D, et al. (2009) Dietary protein, weight loss, and weight maintenance. Ann Rev Nutr 29, 21-41.

5. Westerterp-Plantenga MS, Lemmens SG \& Westerterp KR (2012) Dietary protein - its role in satiety, energetic, weight loss and health. Br J Nutr 108, S105-S112.

6. Bendtsen LQ, Lorenzen JK, Bendsen NT, et al. (2013) Effect of dairy proteins on appetite, energy expenditure, body weight, and composition: a review of the evidence from controlled clinical trials. Adv Nutr 4, 418-438.

7. Luhovyy BL, Akhavan T \& Anderson GH (2007) Whey proteins in the regulation of food intake and satiety. $\mathrm{J} \mathrm{Am}$ Coll Nutr 26, S704-S712.

8. Veldhorst M, Smeets A, Soenen S, et al. (2008) Proteininduced satiety: effects and mechanisms of different proteins. Physiol Behav 94, 300-307.

9. Bellissimo N, Desantadina MV, Pencharz PB, et al. (2007) A comparison of short-term appetite and energy intakes in normal weight and obese boys following glucose and whey-protein drinks. Int J Obes 32, 362-371.

10. Zafar TA, Waslien C, AlRaefaei A, et al. (2013) Whey protein sweetened beverages reduce glycemic and appetite responses and food intake in young females. Nutr Res 33, 303-310.

11. Anderson GH, Tecimer SN, Shah D, et al. (2004) Protein source, quantity, and time of consumption determine the effect of proteins on short-term food intake in young men. J Nutr 134, 3011-3015.

12. Bertenshaw EJ, Lluch A \& Yeomans MR (2008) Satiating effects of protein but not carbohydrate consumed in a between-meal beverage context. Physiol Behav 93, 427-436.

13. Chungchunlam SM, Moughan PJ, Henare S, et al. (2012) Effect of time of consumption of preloads on measures of satiety in healthy normal weight women. Appetite 59, 281-288.
14. Chungchunlam SM, Henare SJ, Ganesh S, et al. (2014) Effect of whey protein and glycomacropeptide on measures of satiety in normal-weight adult women. Appetite 78, 172-178.

15. Lam SM, Moughan PJ, Awati A, et al. (2009) The influence of whey protein and glycomacropeptide on satiety in adult humans. Physiol Behav 96, 162-168.

16. Hall WL, Millward DJ, Long SJ, et al. (2003) Casein and whey exert different effects on plasma amino acid profiles, gastrointestinal hormone secretion and appetite. Br J Nutr 89 , 239-248.

17. Veldhorst MA, Nieuwenhuizen AG, Hochstenbach-Waelen A, et al. (2009) Dose-dependent satiating effect of whey relative to casein or soy. Physiol Behav 96, 675-682.

18. Pal S \& Ellis V (2010) The acute effects of four protein meals on insulin, glucose, appetite and energy intake in lean men. Br J Nutr 104, 1241-1248.

19. Diepvens K, Haberer D \& Westerterp-Plantenga M (2008) Different proteins and biopeptides differently affect satiety and anorexigenic/orexigenic hormones in healthy humans. Int J Obes 32, 510-518.

20. Jahan-Mihan A, Luhovyy BL, El Khoury D, et al. (2011) Dietary proteins as determinants of metabolic and physiological functions of the gastrointestinal tract. Nutrients $\mathbf{3}$, 574-603.

21. Moughan PJ, Fuller MF, Han KS, et al. (2007) Food-derived bioactive peptides influence gut function. Int J Sport Nutr Exerc Metab 17, S5-S22.

22. Alpers DH (1987) Digestion and absorption of carbohydrate and proteins. In Physiology of the Gastrointestinal Tract, pp. 1469-1487 [LR Johnson, editor]. New York: Raven Press.

23. Ten Have GA, Engelen MP, Luiking YC, et al. (2007) Absorption kinetics of amino acids, peptides, and intact proteins. Int J Sport Nutr Exerc Metab 17, S23-S36.

24. Mellinkoff SM, Frankland M, Boyle D, et al. (1956) Relationship between serum amino acid concentration and fluctuations in appetite. J Appl Physiol 8, 535-538.

25. Boirie Y, Dangin M, Gachon P, et al. (1997) Slow and fast dietary proteins differently modulate postprandial protein accretion. Proc Natl Acad Sci U S A 94, 14930-14935.

26. Chungchunlam SM, Henare SJ, Ganesh S, et al. (2015) Dietary whey protein influences plasma satiety-related hormones and plasma amino acids in normal-weight adult women. Eur J Clin Nutr 69, 179-186.

27. Nilsson M, Stenberg M, Frid AH, et al. (2004) Glycemia and insulinemia in healthy subjects after lactose-equivalent meals of milk and other food proteins: the role of plasma amino acids and incretins. Am J Clin Nutr 80, 1246-1253.

28. Nilsson M, Holst JJ \& Bjorck IM (2007) Metabolic effects of amino acid mixtures and whey protein in healthy subjects: studies using glucose-equivalent drinks. Am J Clin Nutr 85 , 996-1004.

29. Etzel MR (2004) Manufacture and use of dairy protein fractions. J Nutr 134, S996-S1002.

30. Moughan PJ (2008) Milk proteins: a cornucopia for developing functional foods. In Milk Proteins: From Expression to Food, pp. 483-499 [A Thompson, M Boland and H Singh, editors]. London: Academic Press.

31. Veldhorst MA, Nieuwenhuizen AG, Hochstenbach-Waelen A, et al. (2009) Effects of complete whey-protein breakfasts versus whey without GMP-breakfasts on energy intake and satiety. Appetite 52, 388-395.

32. Stunkard AJ \& Messick S (1985) The three-factor eating questionnaire to measure dietary restraint, disinhibition and hunger. $J$ Psychosom Res 29, 71-83.

33. Chung Chun Lam SMS (2013) Whey protein and satiety in humans. PhD Thesis, Massey University. 
34. Robel EJ \& Crane AB (1972) An accurate method for correcting unknown amino acid losses from protein hydrolysates. Anal Biochem 48, 233-246.

35. Darragh AJ, Garrick DJ, Moughan PJ, et al. (1996) Correction for amino acid loss during acid hydrolysis of a purified protein. Anal Biochem 236, 199-207.

36. Rutherfurd SM \& Gilani GS (2009) Amino acid analysis. Curr Protoc Protein Sci 11, Unit 11.9, 1-37.

37. Ott L \& Longnecker M (editors) (2010) An Introduction to Statistical Methods and Data Analysis. Belmont, CA: Brooks/Cole Cengage Learning.

38. Pal S, Radavelli-Bagatini S, Hagger M, et al. (2014) Comparative effects of whey and casein proteins on satiety in overweight and obese individuals: a randomized controlled trial. Eur J Clin Nutr 68, 980-986.

39. Gietzen DW (1993) Neural mechanisms in the responses to amino acid deficiency. J Nutr 123, 610-625.

40. Gietzen DW, Erecius LF \& Rogers QR (1998) Neurochemical changes after imbalanced diets suggest a brain circuit mediating anorectic responses to amino acid deficiency in rats. J Nutr 128, 771-781.

41. Waldroup PW, Mitchell RJ, Payne JR, et al. (1976) Performance of chicks fed diets formulated to minimize excess levels of essential amino acids. Poult Sci 55, 243-253.

42. Harper AE (1964) Amino acid toxicities and imbalances. In Mammalian Protein Metabolism, pp. 87-134 [HN Munro and JB Allison, editors]. New York: Academic Press.

43. Harper AE, Benevenga NJ \& Wohlhueter RM (1970) Effects of ingestion of disproportionate amounts of amino acids. Physiol Rev 50, 428-558.

44. Butler RN, Davies M, Gehling NJ, et al. (1981) The effect of preloads of amino acid on short-term satiety. Am J Clin Nutr 34, 2045-2047

45. Garlick PJ (2005) The role of leucine in the regulation of protein metabolism. J Nutr 135, S1553-S1556.

46. Layman DK (2003) The role of leucine in weight loss diets and glucose homeostasis. J Nutr 133, S261-S267.
47. Layman DK \& Walker DA (2006) Potential importance of leucine in treatment of obesity and the metabolic syndrome. J Nutr 136, S319-S323.

48. Ballinger AB \& Clark ML (1994) L-phenylalanine releases cholecystokinin (CCK) and is associated with reduced food intake in humans: evidence for a physiological role of CCK in control of eating. Metabolism 43, 735-738.

49. Pohle-Krauza RJ, Navia JL, Madore EY, et al. (2008) Effects of L-phenylalanine on energy intake in overweight and obese women: interactions with dietary restraint status. Appetite 51, 111-119.

50. Latham CJ \& Blundell JE (1979) Evidence for the effect of tryptophan on the pattern of food consumption in free feeding and food deprived rats. Life Sci 24, 1971-1978.

51. Morris P, Li ET, MacMillan ML, et al. (1987) Food intake and selection after peripheral tryptophan. Physiol Behav 40, 155-163.

52. Kirimura J, Shimizu A, Kimizuka A, et al. (1969) Contribution of peptides and amino acids to the taste of foods. J Agric Food Chem 17, 689-695.

53. Nishimura T \& Kato H (1988) Taste of free amino acids and peptides. Food Rev Int 4, 175-194.

54. Fromentin G, Darcel N, Chaumontet C, et al. (2012) Peripheral and central mechanisms involved in the control of food intake by dietary amino acids and proteins. Nutr Res Rev 25, 29-39.

55. Adibi SA \& Mercer D (1973) Protein digestion in human intestine as reflected in luminal, mucosal, and plasma amino acid concentrations after meals. I Clin Invest 52, 1586-1594.

56. Hegarty JE, Fairclough PD, Moriarty KJ, et al. (1982) Comparison of plasma and intraluminal amino acid profiles in man after meals containing a protein hydrolysate and equivalent amino acid mixture. Gut 23, 670-674.

57. Marrs TC, Addison JM, Burston D, et al. (1975) Changes in plasma amino acid concentrations in man after ingestion of an amino acid mixture simulating casein, and a tryptic hydrolysate of casein. Br J Nutr 34, 259-265.

58. Silk DB, Chung YC, Berger KL, et al. (1979) Comparison of oral feeding of peptide and amino acid meals to normal human subjects. Gut 20, 291-299. 